\title{
The Existence Of Refugees And Immigrants From Middle East In Southeast Asia
}

\author{
Yahya Sultoni*, Khoirul Efendi \\ Wisnuwardhana University, Malang, East Java, Indonesia \\ *Corresponding author: yabyasultoni@wisnuwardhana.ac.id
}

\section{Article history}

Received: 2020-03-25 Received in revised form: 2020-05-06 Accepted: 2020-05-30 Published online: 2020-10-30

\begin{abstract}
Refugees and immigrants are the people who move from a region to another region crossing the countries border for surviving purposes. The reason they migrate to another place moslty because of conflict in their own country, also due to welfare and economic problems. The majority of refugees and immigrant in Indonesia go to Christmas Island, Australia as the final destination seeking the asylum or protection. Automatically they passed the area of the countries in Southeast Asia. It takes a long time for the moving process to the destination country until the status of the determination process for asylum or refugee by UNHCR. Because of the long time, there are fears that the immigrants will impact the stability of national security, economy, social, culture and other aspects. It also considered as demographic problems while increasing population in a country which is traversed by refugees and immigrant. It is important to analyze the influence of the existence of refugees and immigrants, as well as their potential in Southeast Asia Countries. Managing the existence of refugees and immigrant also considered for helping the government and other stakeholders to make the right policy for handling refugees and immigrants.
\end{abstract}

Keywords: Middle East, Refugee, Immigrant, South East Asia. 


\subsection{INTRODUCTION}

Around 1999, several regions of the country in Southeast Asia have been used as a transit point, especially for the movement of people who mostly come from the Middle East region to Christmas Island Australia.

Displacement or large-scale population movement was initially only a domestic problem of a country of origin for refugees and immigrants. Then, because the movement of the population also transcends one country's boundary to another country, this refugee problem eventually becomes a problem of the countries in certain regions and finally it is considered as a common problem of humanity (Romsan, Ahmad, 2003).

The historians and geographers also agree with the opinion that human migration furthermore caused by several factors, including factors climatic conditions that are hostile, lack of food (economics), war (armed conflict, security), and social factors that include political pressure, race, religion and ideology (Meliala, Adrianus, 2011).

It can be realized that the issue of refugee and migration is also included as a serious problem, after the end of the Cold War II, the threat to a country that is military in nature has shifted to the trans-national problem. Threats no longer lead to the state but are more directed at non-state or non-state security threats, both at national, regional and international levels. These threats can be in the form of ethnic conflicts, seizure of natural resources, the spread of disease, economic and technological warfare, the circulation of international narcotics, and the problems of refugees, mass migration and people smuggling (Meliala, Adrianus, 2011).

In this journal is basically having some terminology, firstly that asylum seekers are individuals who are seeking international protection and waiting uncertain of refugee status. Secondly, refugees as individuals who recognized by the 1951 convention relating to refugee status and also to the 1967 protocol, they also recognized as person who receives protection, or obtains s temporary protection in accordance with the United Nations High Commissioner for Refugees (UNHCR) Statute.

The topic about migrants in Indonesia has become a warm issue in recent years. Conflicts in Middle East countries have led to a growing number of immigrants who come to Indonesia. The majority of them make Indonesia as a transit country to continue the journey to Australia. These problems not only be dependent for a country which has ratified the Convention on the Status of the Refugee year 1951 with his Protocol i.e. 1967 Protocol, but also internationally. Moreover, Indonesia has no obligation with the Convention, this means that Indonesia currently has not ratified the 1951 Convention and 1967 Protocol undertook to bear also related the issue of immigrants and refugees. Although Indonesia has not signed the 1951 Convention and the 1967 Protocol, Indonesia at least still have rule of law related problems setting the stranger in law number 6 Year 2011 about Immigration.

Although it already had a legal instrument governing the presence of foreigners through law No. 6 Year 2011 about Immigration, as if still bound to obligations Indonesia related handling of illegal immigrants because of the existence of humanitarian and human rights. Moreover, Indonesia has ratified 7 out of 8 International Human Right Treaties, among others: the CEDAW (Convention on the Elimination of All Forms of Discrimination Against Women); CRC (Convention on the Rights of the Child); ICCPR (the International Covenant on Civil and Political Rights); ICESCR (the International Covenant on Economic, Social, and Cultural Rights); CAT (Covenant Against Torture); ICERD (International Convention on the Elimination of All Forms of Racial Discrimination); and the CRPD (Convention on the Rights of Persons with Disability). 
Some national legal instruments have also been regulated as TAP MPR No. XVII/MPR/1998 which contains the Charter of human rights; Act No. 39 of the year 1999 on human rights; and Act No. 37 Year 1999 concerning Foreign Relations. From some of these legal instruments make Indonesia stuck in the dilemma position in handling of illegal immigrants and refugees, on the one hand Indonesia sued the assertiveness in dealing with illegal immigrants and refugees who enter into the territory of Indonesia, on the other side Indonesia should not declined and cast out the illegal immigrants and refugees directly considering the existence of humanitarian and human rights principles that should be adhered to.

This research uses qualitative research methods because it is related to social and humanitarian problems, according to Creswel that qualitative research implies an effort to explore and understand the meaning of what happens to various individuals or groups, which originate from social or humanitarian issues (Santana K, Septiawan, 2010). For primary data sources, obtained directly from interviews with the authorities dealing with immigrants and refugees living in Java Island and other refugee routes. Stakeholders including Coordinating Ministry for Political, Legal and Security, UNHCR, Police Department, and also Indonesian Research Institute. For secondary data includes supporting data such as the number of immigrants and refugees who entering Indonesia, maps of immigrant entry points, and countries of origin of immigrants and refugees. In this research data, collection techniques will be used in the form of direct observation, interviews, and literature studies. For data analysis, this study used triangulation of data sources that mine the specific information through a variety of methods and sources of data acquisition.

The importance of studying the impact of immigrant and refugee issues, because the issues have an enormous impact for the defense system of the country Indonesia. Furthermore the right handling process is needed considering the impact of the existence of the refugees and immigrants may give rise to conflicts between Nations, which directly affect the defense system of the country Indonesia.

\subsection{HANDLING PROCESS OF REFUGEES AND IMMIGRANTS IN INDONESIA}

UN agencies especially United Nations High Commissioner for Refugees (UNHCR) has the mandate of providing assistance for the protection and maintenance of the refugees to get completion (Ismayawati, Isye, 2013). Considering that Indonesia has yet to ratify the 1951 Convention and the 1967 Protocol on refugees, the handling of refugees in Indonesia predominantly addressed by UNHCR. But lately, the Government of Indonesia launched a President Regulation number 125 years 2016 of The Handling of Refugees from Abroad, from the legislation has set technical rules concerning the handling of the refugees which could be done by the Government. For example with action by discover the immigrants, shelter, security, and control of immigration.

Generally, the process of handling refugees and immigrants made up of several phases starting from the process of arrest or discovery of refugees and immigrants who are transit in Indonesia, then placed in RUDENIM (Detention Home of Immigration) under the auspices of the local immigration office, until the process of determining the status by the UNHCR, and at the end of the process after the determination of refugee status is transferred to a third country or return to their origin country. In waiting for the process of determining the status by the UNHCR refugees and immigrants takes a very long time, their average wait for a period of 1-2 years could be even longer (Masni Eriza, 26 November 2013). Within the granting of the long process of giving the status, feared that the immigrants and refugees raise an impact of stability of national security, economic, social, cultural, and various other aspects for Indonesia.

Page | 79 


\subsection{Demographic Problem of Immigrant in Indonesia}

Each year the number of refugees and asylum seekers are likely to rise. Data in table 1 were obtained from the year 2013 to September 2015 show that the number of refugees has been increasing. While the number of asylum seekers tend to be volatile, since decline and rise.

Table 1 Total Number Refugees and Asylum Seeker Coming into Indonesia

\begin{tabular}{|c|c|c|c|c|}
\hline No & Year & Asylum seeker & Refugees & Total \\
\hline 1 & 2013 & 7.110 & 3.206 & 10.316 \\
\hline 2 & 2014 & 6.348 & 4.456 & 10.804 \\
\hline 3 & 2015 & 7.666 & 5.739 & 13.405 \\
\hline
\end{tabular}

Source: Coordinator Ministry of Political, Legal, and Security Affairs (2016).

It can be seen from the table 1 above that amount on the number of asylum seekers more dominating than the number of refugees, it mean that two groups of immigrants who came to the territory of Indonesia, the number of immigrants who have yet to obtain the status as a refugees are bigger, and adds more load expenses on stakeholders to deal with it until it has been completed, then more time and cost required in the handling of asylum seekers. Another case with immigrants who have got the status of a refugee, it only took several stages for resettlement to a third country.

Data from the period September 2015, if divided by gender that the population of a number such of 13,405 people is divided between 10,055 men 3,350 and women. The population of 3,775 people including children, 1,132 people including children without parent and a separate kid.

Figure 1 Division of Immigrants Based on Shelter

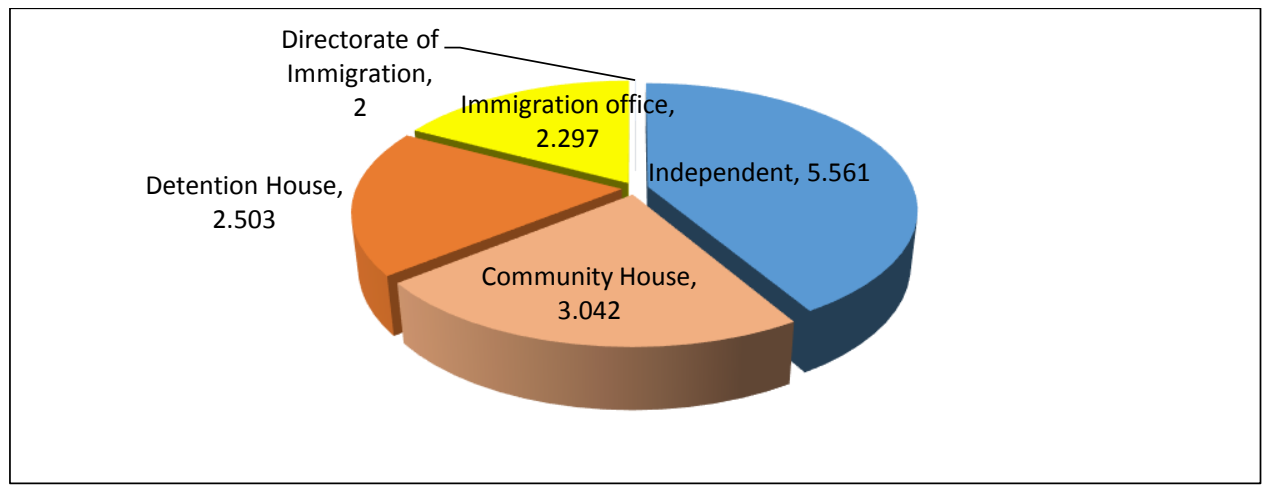

Source: Coordinator Ministry of Political, Legal, and Security Affairs (2016).

As seen in the figure 1 above, the shelter for immigrant and refugees also diverged from some places, among which is housed in Detention House of Migration (Rudenim), the Immigration Office and the Directorate of immigration, and the majority of them are mostly living independently or stay in the community house.

There is a difference in living independently with a stay at the community house. Living independently, namely refugees and asylum seekers the mingling with the local people, they are renting a House with a system of contracts, and the amount of them just four to the front person or one to two families only. Different case with community house, a community house where the big building in the form of an Inn or villa inhabited by many immigrants, the number of residents in the community house is quite a lot that is in the range 50 to 100 person. Refugees and asylum seekers in a community house on average have the same citizenship, in addition to the refugees and asylum seekers in the community one house shaded by one NGO. This means that in a community house inhabited by refugees and asylum seekers from the same country, and take care of their daily lives is the same NGO's. The NGO's which taking care in some community house 
of which the High Commissioner of the United Nations for Refugees (UNHCR), the International Organization of Migration (IOM), and the Jesuit Refugee Service (JRS). Each of these houses and NGO's were responsible in some community house scattered in several places. Including logistics and program needs to take care of daily activities.

The main problem faced by the Government of Indonesia's currently as the problems of the resettlement process or moving process the refugees to the third country. Expectations of the Indonesian Government that its territory was used as a transit country, refugees and asylum seekers that is in the process of handling appropriately and optimally, assisted by humanitarian organizations that exist, so that there are no more refugees the displaced in the region of Indonesia territory. But in fact, the number of immigrants who enter the territory of Indonesia is not proportional with the number of refugees who have been through the process of being moved to third countries.

Table 2 Resettlement Data of Refugees

\begin{tabular}{|l|r|r|r|r|r|}
\hline \multicolumn{1}{|c|}{ Countries } & $\mathbf{2 0 1 2}$ & $\mathbf{2 0 1 3}$ & $\mathbf{2 0 1 4}$ & $\begin{array}{c}\text { (till 2015 } \\
\text { Sept) }\end{array}$ & Total \\
\hline Australia & 189 & $\mathbf{8 1 5}$ & 532 & 333 & $\mathbf{1 , 8 6 9}$ \\
\hline Canada & 1 & 0 & 7 & 5 & $\mathbf{1 3}$ \\
\hline Denmark & 0 & 0 & 1 & 0 & $\mathbf{1}$ \\
\hline Finland & 0 & 0 & 0 & 0 & $\mathbf{0}$ \\
\hline France & 0 & 0 & 0 & 0 & $\mathbf{0}$ \\
\hline New Zealand & 53 & 78 & 115 & 0 & $\mathbf{2 4 6}$ \\
\hline Norway & 0 & 0 & 0 & 0 & $\mathbf{0}$ \\
\hline Sweden & 9 & 7 & 0 & 0 & $\mathbf{1 6}$ \\
\hline United Kingdom & 0 & 0 & 0 & 0 & $\mathbf{0}$ \\
\hline United States & 5 & 0 & 95 & 74 & $\mathbf{1 7 4}$ \\
\hline Romania & 0 & 0 & 0 & 0 & $\mathbf{0}$ \\
\hline Philipine & 0 & 0 & 0 & 0 & $\mathbf{0}$ \\
\hline German & 0 & 0 & 98 & 16 & $\mathbf{1 1 4}$ \\
\hline Total & $\mathbf{2 5 7}$ & $\mathbf{9 0 0}$ & $\mathbf{8 4 8}$ & $\mathbf{4 2 8}$ & $\mathbf{2 , 4 3 3}$ \\
\hline
\end{tabular}

Source: Coordinator Ministry of Political, Legal, and Security Affairs (2016).

As seen in table 2, the date shows the resetllment of refugees. Comparing the data from desk of People Smuggling, Refugees and Asylum Seekers (PPMPPS) Coordinator Minister of Political, Legal and Security Affairs, per September 2015 with total population of 13,405 coming into the territory of Indonesia will look a lot more, than refugees who have been through the process of resettlement only reached 428 people in the year 2015. It is only 3.2 percent of the number of refugees who have been through the process of resettlement, while immigrants who enter the territory of Indonesia is already more than ten thousand each year.

If seen from the table above, that Australia the countries that became the main goal of the refugees and asylum seekers, arguably the most countries that receive refugees annually than any other country. In the year 2015 Australia only able to receive as much as 333 refugees only. Even if compared to previous years, the acceptance of the year 2015 just a bit, because in the year 2014 Australia able to accept refugees as much as 532 refugees and greater quantities again in 2013 as much as 815 refugees.

A couple of years New Zealand as a country a rather open up for the resettlement, last year 2014 data that demonstrates the capabilities of the New Zealand receive refugees a bit much. Such disclosure can also be done by some countries in Europe for resettlement, but now the European countries also could not open up because of the large number of refugees flooded already much for from Syria, and this has become the instability of population (Tri Nuke Pudjiastuti, October 2016). 
If the cycle of resettlement still goes by the number of the data above, then it may occur the stack phenomenon of immigrants in the territorial area of Indonesia. Apart from fundamental human rights would have an obligation to protect the rights of the refugees live, more citizens of other countries who came to the territory of Indonesia certainly will add impact to national stability.

\subsection{How ASEAN Countries Handling the Refugees and Immigrants.}

ASEAN as a supporting organization for southeast countries does not have a proper mechanism to manage refugees and immigrants. From ten members of ASEAN, only Cambodia and the Philippines have signed the 1951 Refugee Convention. Rohingya refugee recipient countries also do not have a certain legal framework to grant protection or legal for refugees and asylum seekers (Bangun, Budi Hermawan, 2017).

In a Rohingya refugee case, the management of refugees is harder to handle due to the lack of ASEAN countries' cooperation. It seems that only a few countries, Indonesia, Malaysia, and Thailand, pay serious attention and afford proactive solutions in dealing with this case (Bangun, Budi Hermawan, 2017).

Some reasons why certain countries become a destination, for instance, Malaysia, are its economical welfare, Islamic culture, and its big population of Rohingya. Meanwhile, Indonesia has become a destination since the heroic moment when Aceh fishermen rescued Rohingya refugees and Bangladesh immigrants who were stranded at the sea, hoping to be accepted in the destination country.

Unfortunately, those destination countries reject Rohingya's arrival. Even Thailand government-issued a clear statement regarding Rohingya's arrival, by stating that Rohingya refugees are not accepted in Thailand. Malaysia and Indonesia issued a similar statement as well. Malaysia Minister of Home Affairs, Wan Junaidi Jafaar, stated that Malaysia is able to provide food and treat well Rohingya refugees, but not grant accommodation for them. The General of the Indonesian Army, Moeldoko, claimed that Indonesia will continue to provide aids for refugees from Myanmar, still, Indonesia prohibits refugees to enter or pull over on Indonesia land (Sawal, 2017). However, after getting critics from international citizens and appeal from the United Nations, those three destination countries agreed to accept Rohingya refugees.

\subsection{ASEAN'S DEMOGRAPHIC DATA}

Based on the data, there are four countries that are dominated as the host to accommodate refugees and immigrants, Malaysia, Thailand, Indonesia, and the Philippines. Those countries have a different percentage on the number of refugees handled. In 2016, the biggest population of refugees is in Malaysia with $59.6 \%$ or 92,054 people. The second biggest population is in Thailand with $35.1 \%$ or 54,251 people. Indonesia has a third place with $4.9 \%$ or 7627 people. And the last is the Philippines with $0.3 \%$ or 408 people. 
Figure 2 Host Country of Refugees in Southeast Asia

\section{Breakdown of Refugees in Southeast Asian Host}

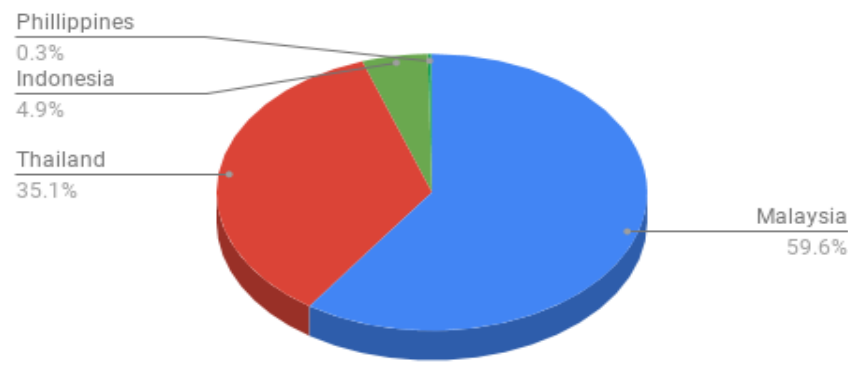

In each destination country, the refugees and immigrants are from various countries or in other words heterogeneous countries of origin. The breakdown of host country is shown in figure 2. The figure shows that the dominating country of origin differs in each destination country. It depends on the geographical condition, political policy, and socio-cultural environment.

\subsection{Malaysia}

In the case of Malaysia, the dominating refugees in Malaysia, which is $94.8 \%$ or around 87,000 people are from Myanmar. (Rohingya history) After the conflict in 2012, Rohingya eagerly escaped from Myanmar. This can be seen in figure 3. The United Nations High Commissioner for Refugees stated that more than 100,000 people of Rohingya ethnic and Bangladesh have left Myanmar by using boats since 2012 .

Figure 3 Refugees in Malaysia

\section{Breakdown of Refugees in Malaysia}

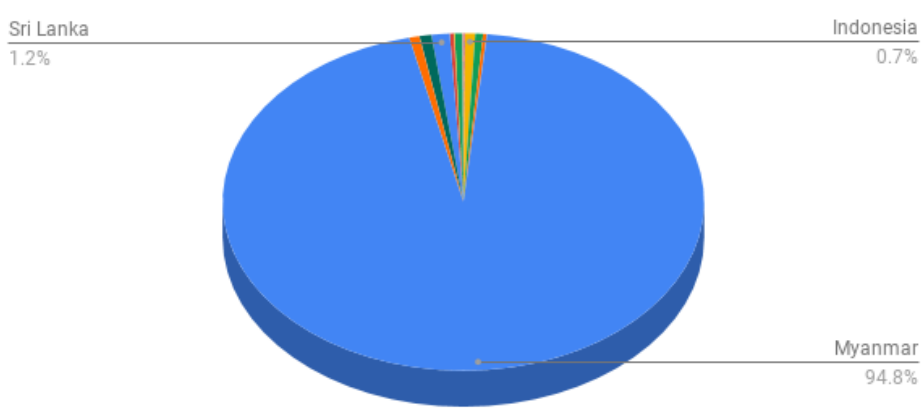

Furthermore, the UNHCR Maritime Surveillance Unit clarified that from June 2012 to August 2014, around 87,000 people of Rohingya and Bangladesh undertook risky sea journey from Bengal Bay. The refugees finally landed in Malaysia, some in Indonesia. Besides Rohingya refugees who dominated in Malaysia, there are also 1.2\% refugees from Sri Lanka or around 1,120 people, and the others are from Afganistan, Cambodia, Iraq, Iran, Indonesia, Pakistan, Somalia, Palestine, and Syria, which are totally under 1000 people. 


\subsection{Thailand}

A similar condition also happened in Thailand with the majority of refugees are Rohingya from Myanmar. As depicts in figure 4, the percentage in 2016 reached 93\% or 102,633 people. From the data, it showed that the number of Rohingya refugees in Thailand is bigger than in Malaysia. The second biggest refugee population in Thailand is from Pakistan with 3.4\% or 1,825 people. The others are from Iraq, Palestine, Syria, Vietnam, and other various countries, with each of which is less than $1 \%$ or 200 people on average.

Figure 4 Refugees in Thailand

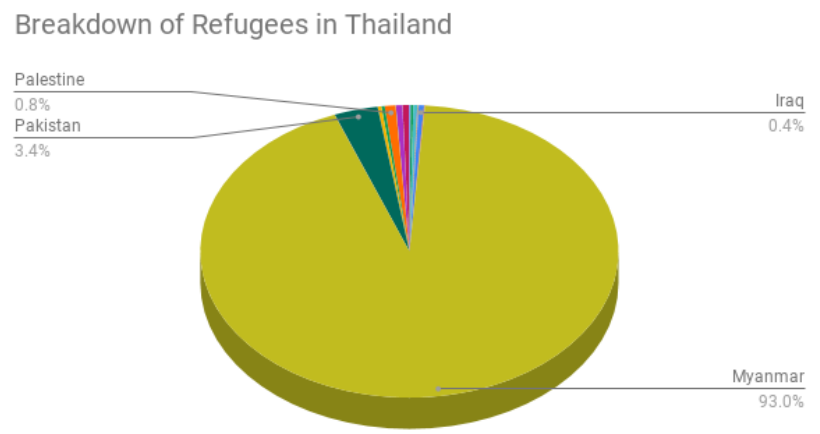

\subsection{Indonesia}

In the previous data, Malaysia and Thailand are dominated by Rohingya refugees with more than $90 \%$, which is different from Indonesia.

Figure 5 Refugees in Indonesia

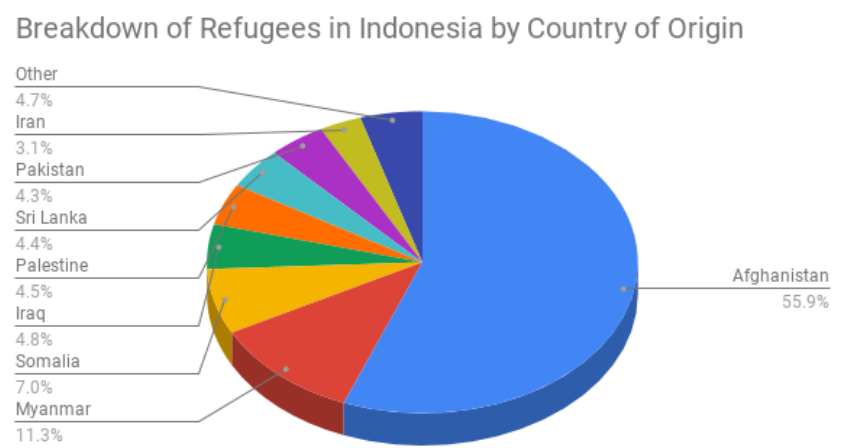

Meanwhile, refereeing to the figure 5, the dominating refugees in Indonesia are from Afghanistan with $55.9 \%$ or 4,379 people, while Rohingya is in second place with $11.3 \%$ or 887 people, and the third place is from Somalia with $7 \%$ or around 548 people. The others are from Iran, Iraq, Pakistan, Sri Lanka, and Palestine, in which around 4\% for each or around 300 people.

\subsection{Philippines}

The different conditions also happened in the Philippines, in which the country of origin is more heterogeneous, and the population is not big. This can be seen in figure 6 . The refugees in the Philippines are from various countries and some countries which dominated do not have a big population. 
For example, Iran as the dominating country of origin only has 57 people or $14 \%$. Meanwhile, refugees from Syria, Palestine, Pakistan, and Iraq have a similar population, around $9-11 \%$ or 40 50 people. Some other countries with a smaller percentage, around $5 \%$ to $2 \%$ are Vietnam, Sri Lanka, Somalia, Eritrea, Rwanda, Côte d'Ivoire, Myanmar, and Afghanistan. The significant difference is that the Rohingya population in the Philippines is only $2.5 \%$ or 10 people, which is far different from the condition in Malaysia and Thailand. Besides, for Afghanistan refugees in the Philippines is only $2.9 \%$ or 12 people, which is different from the number in Indonesia reaching 4,379 people.

Figure 7 shows the data of the refugee population in the four host countries. Generally, Myanmar dominated with almost 90\% number of refugees living in ASEAN. Then it is followed by other countries, such as Afghanistan, Pakistan, Sri Lanka, Somalia, Iraq, Palestine, and Syria, with each of which is around $1 \%$ to $3 \%$.

Figure 6 Refugees in Philipines

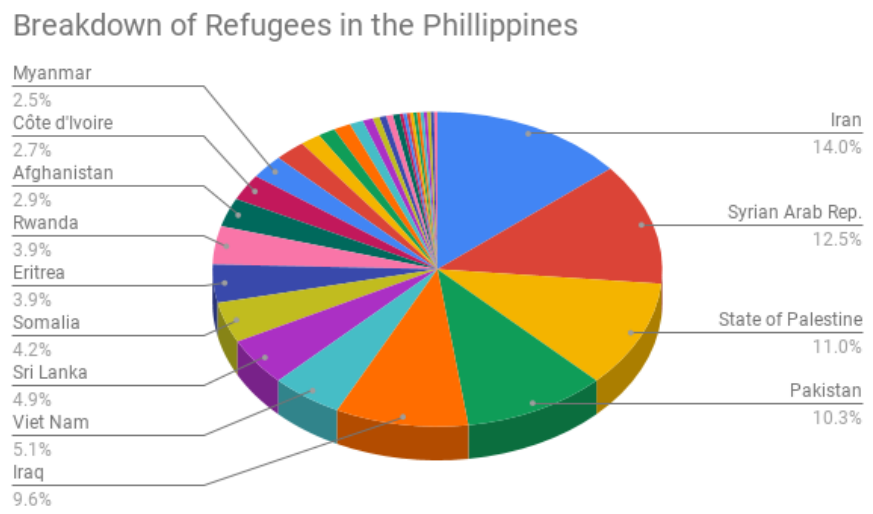

Figure 7 Refugee's Country of Origin in Southeast Asia

Breakdown of Refugees by Country of Origin in Southeast Asia

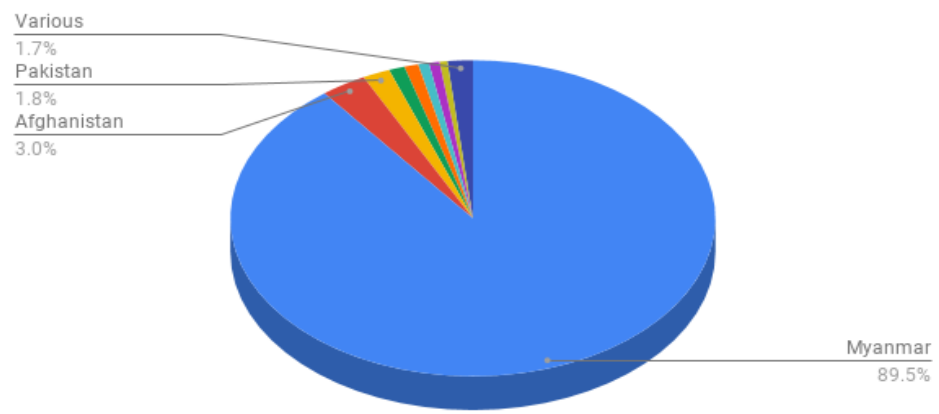

Based on the elaborated data, refugees and immigrants problem is not only dominated by Middle East countries, but refugees from Myanmar, or known as Rohingya, need to be seriously noticed due to its big population and mobility around ASEAN regional. It is strongly suggested that ASEAN countries design homogeneous policy regarding the refugee problem to be applied in each country where refugees are living. 


\subsection{CONCLUSION}

The refugee and migration problems are a very complex problem. Refugees and immigrants move to another place for many reasons, among others because of conflict in the country of origin, also due to welfare and economic problems. Demographic conditions of a country also influence due to the presence of refugees. But it would be good condition if the immigrant problems are carefully handled, then there is a process of acculturation between groups, as well as the process of placement, supervision, and appropriate shelter for immigrants.

ASEAN as a supporting organization for southeast countries does not have a proper mechanism to manage refugees and immigrants. It seems that only a few countries, Indonesia, Malaysia, and Thailand, pay serious attention and afford proactive solutions in dealing with refugee and immigrant issues.

Refugees and immigrants' problem is not only dominated by Middle East countries, but refugees from Myanmar, or known as Rohingya, need to be seriously noticed due to its big population and mobility around ASEAN regional. Hopefully through the ASEAN countries forum could design homogeneous policy regarding the refugee problem to be applied in each country where refugees are living.

\section{List of Reference}

Bangun, Budi Hermawan (2017), Tantangan ASEAN dalam Melakukan Penanganan Pengungsi Rohingya, PADJAJARAN Jurnal Ilmu Hukum 4(3), 570 available at http://journal.unpad.ac.id/pjih/article/view/14929/7213

Pudjo Laksono, (2016), Interview data from desk of people smuggling, refugees and asylum seekers. Coordinator Ministry of Political, Legal, and Security Affairs, Indonesia

Ismayawati, Isye, (2013), Manusia Perahu: Tragedi Kemanusiaan di Pulau Galang, Jakarta: Penerbit Buku Kompas, 78.

Masni Eriza (26 November 2013), Interview by head of sub division Humanity, Human Right \& Multilateral Directory, Ministry of Foreign Affairs.

Meliala, Adrianus (2011), Pemantapan Legalitas dan Kebijakan Menyangkut Penyelundupan Manusia, Depok: FISIPOL Universitas Indonesia, 2.

Romsan, Ahmad (Eds) (2003), Pengantar Hukum Pengungsi Internasional: Hukum Internasional dan Prinsip-Prinsip Perlindungan Internasional, UNHCR Perwakilan Regional Jakarta, Republik Indonesia, Bandung: Percetakan Sanic Offset, 3.

Santana K, Septiawan (2010) Menulis Ilmiah Metodologi Penelitian Kualitatif (2nd ed)., Jakarta: Yayasan Pustaka Obor Indonesia, Page 1.

Sawal, Indah ANggriani (2017) Implikasi Krisis Kemanusiaan Rohingya di Myanmar terhadap NegaraNegara ASEAN, skripsi, FISIPOL Universitas Hasanuddin, Makassar, 7.

Tri Nuke Pudjiastuti, (2016), Interview by LIPI Researcher of Migration in Regional of ASEAN 